\title{
Implementasi Kebijakan Pemanfaatan Sewa Barang Milik Negara: Tanah Pengairan Solo Valley Warken Kabupaten Lamongan (Studi di Desa Pelangwot Kecamatan Laren dan Desa Sedayulawas Kecamatan Brondong)
}

\author{
Raharwindy Kharisma Sudrajat ${ }^{a *}$, Alfi Haris Wanto ${ }^{b}$, Bambang Supriyono $^{c}$ \\ ${ }^{a b c}$ Universitas Brawijaya, Jawa Timur, Indonesia
}

\section{INFORMASI ARTIKEL}

\section{Article history:}

Dikirim tanggal: 22 Maret 2021

Revisi pertama tanggal: 26 Maret 2021

Diterima tanggal: 29 Maret 2021

Tersedia online tanggal: 15 April 2021

Keywords: implementation of policies, lease Utilization, Solo Valley Warken Irrigation Land

\begin{abstract}
After the development of the floodway, the Solo Valley Warken Irrigation Land that has not been and is not used for irrigation needs can be used by the subject of the lease by paying a fee that has been determined by the Public Works Office for Water Resources (SDA) of Lamongan Regency so that it can be used to meet the needs of community land. which is increasing. As for the fees that are generated each year, it will be divided according to the cooperation agreement between the Public Company (PERUM) Jasa Tirta I and the Autonomous Regional Government of Lamongan Regency. Although the ratio of effectiveness between the target of receiving retribution and revenue realization is very effective, its contribution to PAD in Lamongan Regency is still far below the average.
\end{abstract}

\section{INTISARI}

Pasca pembangunan sudetan floodway, Tanah Pengairan Solo Valley Warken yang belum dan tidak digunakan untuk kebutuhan pengairan dapat dipergunakan oleh subyek sewa dengan membayar biaya retribusi yang sudah ditetapkan besarnya melalui Dinas PU Sumber Daya Air (SDA) Kabupaten Lamongan agar dapat didayagunakan untuk memenuhi kebutuhan tanah masyarakat yang semakin meningkat. Adapun retribusi yang dihasilkan setiap tahunnya akan dibagi sesuai perjanjian kerjasama antara Perusahaan Umum (PERUM) Jasa Tirta I dengan Pemerintah Daerah Otonom Kabupaten Lamongan. Meskipun rasio efektifitas antara target penerimaan retribusi degan realisasi penerimaan sudah sangat efektif, akan tetapi kontribusi terhadap PAD Kabupaten Lamongan masih jauh dibawah rata-rata.

\section{Pendahuluan}

Tanah mempunyai arti penting dalam kehidupan manusia karena tanah mempunyai fungsi ganda, yaitu sebagai social asset dan capital asset. Sebagai social asset tanah merupakan sarana pengikat kesatuan sosial di kalangan masyarakat Indonesia untuk hidup dan kelangsungan hubungan sosial, sedangkan sebagai capital asset tanah merupakan faktor modal dalam pembangunan. Kebutuhan akan tanah pada setiap tahunnya akan meningkat sejalan dengan meningkatnya jumlah penduduk di Indonesia, sedangkan jumlah ketersediaan tanah tetap.

Bertumpu pada Pasal 33 ayat 3 dan 4 yang diamanatkan dalam Undang-Undang Dasar Negara 
Republik Indonesia Tahun 1945 yang berisikan: "Bumi, air dan kekayaan alam yang terkandung di dalamnya dikuasai oleh negara dan dipergunakan sebesar-besarnya kemakmuran rakyat", dan juga bahwasannya "perekonomian nasional diselenggarakan berdasarkan atas demokrasi ekonomi dengan prinsip kebersamaan, berkeadilan, berkelanjutan, berwawasan lingkungan, kemandirian, serta dengan menjaga keseimbangan kemajuan dan kesatuan ekonomi nasional". Kebijakan pemerintah dibutuhkan untuk dapat memenuhi kebutuhan akan tanah bagi setiap warga negaranya.

Terdapat beberapa kebijakan sebagai bentuk pemerataan akan kebutuhan tanah di Indonesia, yang penulis uraikan menjadi tiga bagian. Pertama, kebijakan Redistribusi Tanah Obyek Reforma Agraria (TORA) dengan ganti rugi yang diatur dalam Peraturan Presiden Republik Indonesia No. 86 Tahun 2018 tentang Reforma Agraria. Reforma Agraria, atau dalam Undang-undang Pokok Agraria lebih dikenal dengan istilah landreform, merupakan penataan kembali struktur penguasaan, pemilikan, penggunaan dan pemanfaatan tanah yang lebih berkeadilan melalui penataan aset dan disertai dengan penataan akses untuk kemakmuran rakyat Indonesia.

Kedua, kebijakan penggunaan kekayaan negara (pusat dan daerah) yang diatur dalam Peraturan Menteri Agraria atau Kepala Badan Pertanahan Nasional No. 9 Tahun 1999 tentang Tata Cara Pemberian dan Pembatalan Hak atas Tanah Negara dan Hak Pengelolaan; guna menjamin kebutuhan akan tanah di Indonesia. Dimana tanah negara menurut Sumardjono (2009, h. 144) adalah tanah yang tidak dilekati dengan suatu Hak Atas Tanah. Sejalan dengan definisi tersebut, Chomzah (2002, h. 1) juga menyatakan bahwa tanah negara adalah tanah yang tidak dipunyai oleh perseorangan atau badan hukum dengan suatu Hak Atas Tanah sesuai dengan ketentuan yang berlaku.

Ketiga, kebijakan pemanfaatan Barang Milik Negara dan Daerah, yang selanjutnya disingkat dengan menggunakan BMN dan BMD dalam bentuk sewa. BMN dan BMD dalam Pasal 1 ayat (10) dan (11) UndangUndang No. 1 Tahun 2004 tentang Perbendaharaan Negara; keduanya merupakan barang (tanah atau bangunan) yang dibeli atau diperoleh atas beban Anggaran Pendapatan dan Belanja Negara (APBN) untuk BMN dan atas beban Anggaran Pendapatan dan Belanja Daerah (APBD) untuk BMD atau dari perolehan lainnya yang sah.

Secara lebih khusus, pemanfaatan dalam bentuk sewa atas BMN, diatur dalam Peraturan Menteri No. 57/PMK.06/2016 tentang Tata Cara Pelaksanaan Sewa Barang Milik Negara. Kebijakan tersebut pada dasarnya bertujuan untuk mengoptimalkan pemanfaatan BMN yang belum atau tidak digunakan dalam pelaksanaan tugas dan fungsi penyelenggaraan negara, memperoleh fasilitas yang diperlukan dalam rangka menunjang tugas dan fungsi instansi pengguna barang dan untuk mencegah penggunaan BMN oleh pihak lain secara tidak sah. Pemanfaatan BMN dalam bentuk sewa hanya dapat dilakukan sepanjang tidak merugikan negara dan tidak mengganggu pelaksanaan tugas dan fungsi penyelenggaraan pemerintahan, serta penyewa tidak dapat menyewakan kembali BMN kepada pihak lain, kecuali dengan persetujuan pengelola barang.

Tanah Solo Valley Warken merupakan tanah peninggalan pemerintah Hindia Belanda yang digunakan untuk saluran induk luapan air Bengawan Solo dan pengendalian banjir. Pada Tahun 1890-1898 dilaksanakan program Pembangunan Pengendalian dan Pembuatan Jaringan Irigasi di Kabupaten Bojonegoro, Tuban, Lamongan, dan Gresik diatas tanah perpajakan atau perorangan yang telah dibebaskan menjadi tanah negara sepanjang $165 \mathrm{~km}$ dan lebar $150 \mathrm{~m}$.

Program pembangunan pembuatan saluran induk dimulai Tahun 1893 sampai dengan Tahun 1898 dan akhirnya ditangguhkan selama 32 tahun dan dihentikan pada Tahun 1930. Selama masa penangguhan pembangunan tersebut, tanah Solo Valley Werken disewakan kepada masyarakat petani dan masyarakat sekitar sebagai lahan pertanian yang disewa melalui Dinas Pekerjaan Umum Pengairan Daerah Tingkat I Provinsi Jawa Timur. Di Tahun 1972 dilakukan penertiban dan inventarisasi serta untuk kegiatan pembangunan dan pemanfaatan Solo Valley Warken dilanjutkan oleh Balai Besar Wilayah Sungai Bengawan Solo yang bertanggungjawab kepada Menteri Pekerjaan Umum dan Perumahan Rakyat (PUPR) dengan melaksanakan studi diantaranya adalah Rencana Induk Pengembangan dan Pengelolaan Wilayah Sungai Bengawan Solo atau yang lebih dikenal dengan CDMP (Comprehensive Development and Management Plan); Pola Pengelolaan Sumber daya Air Wilayah Sungai Bengawan Solo; Rencana Pengelolaan Sumber daya Air Wilayah Sungai Bengawan Solo; dan Kajian Solo Valley Werken sebagai Pengendali Banjir di Kabupaten Ngawi, Bojonegoro, Lamongan, dan Gresik.

Peran penting pembangunan Solo Valley Warken adalah sebagai tampungan air untuk irigasi, mengatasi kekeringan di Kabupaten Bojonegoro, Lamongan, dan Gresik. Selain itu juga sebagai long storage bagi air sebelum masuk ke Sungai Bengawan Solo Hilir, dengan mempercepat aliran sungai menuju ke laut melalui pembangunan sudetan floodway yang salah satunya dibangun memanjang dan terletak di Desa Pelangwot sampai dengan Desa Sedayu Lawas di Kabupaten Lamongan yang merupakan daerah hilir dari Sungai Bengawan Solo.

Mengingat fungsi tanah sebagai social asset dan capital asset, kelebihan Tanah Pengairan Solo Valley Warken yang belum dan tidak digunakan untuk 
kebutuhan pengairan, dapat disewa oleh subjek sewa dengan membayar retribusi yang ditetapkan besarannya oleh pengelola dan pengguna melalui Dinas PU Sumber Daya Air (SDA) Kabupaten Lamongan yang ditempat tugaskan di Kecamatan Karanggeneng, agar dapat didayagunakan untuk memenuhi kebutuhan tanah masyarakat yang semakin meningkat.

Tanah Pengairan Solo Valley Warken yang hanya dipergunakan untuk pembangunan sudetan floodway seluas $13 \mathrm{~km}$ dengan lebar 100 meter, tanah kelebihan yang belum difungsikan banyak dimanfaatkan oleh masyarakat setempat tanpa menggunakan prosedur yang sah dan berpotensi merugikan negara maupun daerah. Oleh sebab itu mengkaji sebuah implementasi kebijakan pemanfaatan sewa Tanah Pengairan Solo Valley Warken dipandang penulis perlu untuk dilakukan dikarenakan besarnya potensi social asset dan capital asset dari pemanfaatan Tanah Pengairan Solo Valley Warken, disamping banyaknya pemanfaatan yang tidak sesuai dengan prosedur yang ditetapkan yang termasuk dalam perbuatan yang merugikan, mengganggu pelaksanaan tugas dan fungsi penyelenggaraan pemerintahan negara sebagaimana yang telah diatur dalam Peraturan Menteri No. 57/ PMK.06/ 2016 tentang Tata Cara Pelaksanaan Sewa Barang Milik Negara.

Berdasarkan latar belakang yang telah diuraikan diatas, penelitian ini dilakukan untuk menganalisis implementasi, faktor penghambat, faktor pendukung, dan kontribusi terhadap retribusi dari pemanfaatan sewa barang milik negara: Tanah Pengairan Solo Valley Warken di Kabupaten Lamongan (Studi di Desa Pelangwot dan Desa Sedayulawas).

\section{Teori}

\subsection{Implementasi Kebijakan Publik}

Suatu program kebijakan harus diimplementasikan agar mempunyai dampak atau tujuan yang diinginkan. Jones (dalam Widodo, 2018, h. 86) mengartikan implementasi sebagai getting the job done "and" doing it. Menurut Jones, pelaksanaannya menuntut adanya beberapa sumber daya (resource), antara lain adanya orang atau pelaksana, uang dan kemampuan organisasi yang selanjutnya oleh Jones dirumuskan batasan implementasi sebagai "a process of getting additional resource so as to figure out what is to be done", yang dapat diinterpretasikan sebagai proses penerimaan sumber daya tambahan sehingga dapat mengukur apa yang harus dikerjakan, dengan merumuskan tindakan apa yang harus dilakukan serta melaksanakan tindakan yang telah dirumuskan.

Van Meter \& Van Horn (dalam Winarno, 2016, h. 142-149) merumuskan model implementasi kebijakan yang menghubungkan enam variabel bebas yang terdiri dari, sebagai berikut: a) Ukuran-ukuran dasar dan tujuan-tujuan kebijakan;

b) Sumber-sumber kebijakan;

c) Komunikasi antarorganisasi dan kegiatan-kegiatan pelaksanaan;

d) Karakteristik badan-badan pelaksana;

e) Kondisi-kondisi ekonomi, sosial dan politik; dan

f) Kecenderungan pelaksana (implentator) dengan kebijakan dan kinerja sebagai variabel terikat.

Model yang dikembangkan oleh Van Meter \& Van Horn merupakan model yang menawarkan blueprint untuk menjelaskan dan menganalisa proses implementasi kebijakan, sehingga mengusulkan penjelasan bagi pencapaian dan kegagalan program dari kebijakan pemanfaatan sewa Tanah Pengairan Solo Valley Warken di Kabupaten Lamongan.

\subsection{Good Governance}

Konsepsi kepemerintahan pada dasarnya merujuk pada proses interaksi sosial politik antara pemerintah dengan masyarakat dan proses berfungsinya pemerintahan dalam rangka memenuhi kebutuhan masyarakat sesuai aspirasi dan kepentingan masyarakat pada berbagai bidang baik ekonomi, sosial, politik dan sebagainya. Dengan demikian, terdapat tiga stakeholder antara lain, sebagai berikut:

a) Pemerintah dengan menciptakan lingkungan politik dan hukum yang kondusif;

b) Swasta yang menciptakan pekerjaan dan pendapatan; dan

c) Masyarakat yang berpartisipasi dalam aktivitas ekonomi, sosial dan politik.

Sehingga ketiganya senantiasa berinteraksi untuk memajukan ekonomi, sosial dan politik suatu negara (Moenek \& Suwanda, 2019, h. 55).

Good governance merupakan sebuah konsep menggenai pemerintahan terkait dengan proses birokrasi dan pengambilan kebijakan yang berupaya untuk memenuhi aspek-aspek keterbukaan informasi dan pemenuhan kebutuhan masyarakat secara tepat. Sehingga istilah "good governance" diartikan dengan sistem pemerintahan yang baik. Office of the High Commissioner for Human Rights PBB memiliki empat faktor utama yang ditetapkan dalam resolusi PBB Nomor 2000/64 ( Winarno, 2016, h. 429), yaitu: transparansi, tanggung jawab, akuntabilitas, partisipasi masyarakat, serta responsivitas atau ketanggapan (responsiveness) terhadap kebutuhan masyarakat

Dikembangkannya konsep Good Governance tidak hanya menuntut kemampuan dan profesionalitas aparatur negara dalam pelayanan publik, secara fundamental juga menunut terwujudnya budaya pemerintahan yang baik dan bersih (good governance and clean governance cultures). Sedangkan globalisasi mencakup segala aspek bidang yang juga menuntut adanya reformasi sistem perekonomian antar daerah dan bangsa yang berlangsung 
secara efesien. Dalam hubungan inilah pelayanan sebagai salah satu fungsi pemerintah pada tingkat operasionalnya harus dapat melindungi dan memenuhi hal-hal lain yang menjadi tuntutan serta kebutuhan masyarakat yang dilakukan secara menyeluruh dari segala aspek bidang kehidupan berbangsa dan bernegara.

\subsection{Manajemen Aset Kekayaan Negara: Pengelolaan Barang Milik Negara dan Barang Milik Daerah}

Aset secara umum didefinisikan oleh Siregar (2004, h. 178) sebagai suatu barang yang mempunyai nilai ekonomi, nilai komersial atau nilai tukar yang dimiliki oleh badan usaha, instansi atau individu, sedangkan menurut Hanafi (2003, h. 24), aset merupakan aktiva atau berarti sumber daya yang dikuasai oleh pemerintah sebagai akibat dari peristiwa masa lalu dan darinya manfaat ekonomi di masa depan diharapkan akan diraih oleh pemerintah. Kedua pengertian tersebut, dapat penulis simpulkan bahwa aset atau aktiva adalah bentuk dari penanaman modal baik oleh pemerintah pusat ataupun daerah yang dapat berupa harta kekayaan dan diharapkan mampu memberikan kontribusi baik secara langsung maupun tidak langsung di masa yang akan datang.

Berberapa aset yang ada, perlu dilakukan proses manajemen aset sebagai suatu kegiatan manajemen dalam pengelolaan dan penggunaan dana yang ditujukan dalam rangka meningkatkan kontrol atau pengawasan terhadap aset tetap dan revaluasi aset tetap yang disesuaikan dengan nilai wajar. Siregar (2002, h. 48) mengemukakan, bahwa manajemen aset membutuhkan keahlian yang belum sepenuhnya berkembang dan populer dilingkungan pemerintahan maupun disatuan kerja atau istansi.

Menurut Mahmudi (2009, h. 155), manajemen aset kedepannya terdiri dari lima tahapan kerja yang satu sama lainnya terkait, yaitu sebagai berikut:

a) Inventarisasi Aset;

b) Legal Audit;

c) Penilaian Aset;

d) Optimalisasi Aset; dan

e) Pengembangan Sistem Informasi Manajemen Aset (SIMA)

Berdasarkan beberapa definisi yang sudah dijelaskan diatas, dapat disimpulkan bahwa aset atau aktiva merupakan sumber daya yang dimiliki oleh negara yang diharapkan dapat memberikan keuntungan baik dimasa sekarang maupun masa depan. Adapun pengelolaan aset tersebut harus diinventaris dengan baik, dilakukan legal audit, optimalisasi dan dilakukan pengembangan Sistem Informasi Manajemen Aset (SIMA) baik oleh pemerintah pusat maupun pemerintah daerah.

\section{Metode Penelitian}

Desain penelitian ini menggunakan pendekatan kualitatif deskriptif dengan melakukan wawancara secara mendalam terhadap stakeholders yang ditunjuk langsung oleh Dinas Pekerjaan Umum dan Sumber Daya Air Kabupaten Lamongan; observasi partisipan dan non partisipan; dan studi dokumentasi.

Sedangkan tahapan penelitian ini diantaranya: melakukan identifikasi data secara lebih mendalam terhadap problem; melakukan identifikasi aktor dan peranan keterlibatan dan melakukan crosscheck data terhadap pihak-pihak yang terlibat dalam implementasi Pemanfaatan Sewa Tanah Pengairan Solo Valley Warken dan lebih spesifik di Desa Pelangwot dan Desa Sedayulawas di wilayah Kabupaten Lamongan (melalui wawancara maupun observasi); menghimpun data yang telah dikumpulkan berdasarkan fokus penelitian; melakukan analisis data; serta penarikan kesimpulan.

Mengambil lokasi penelitian di wilayah Kabupaten Lamongan, penelitian dilakukan dibeberapa institusi/ lembaga pemerintah, serta individu yang terkait dalam implementasi pemanfaatan sewa tanah pengairan Solo Valley Warken, antara lain Dinas PU SDA Kabupaten Lamongan, UPT Pengelolaan Sumber Daya Air Karanggeneng, Dinas Perencanaan Pembangunan Daerah Kabupaten Lamongan, Dinas Penanaman Modal dan Pelayanan Terpadu Satu Pintu Kabupaten Lamongan, Desa Pelangwot di Kecamatan Laren dan Desa Sedayulawas di Kecamatan Brondong.

\section{Hasil Penelitian dan Pembahasan}

\subsection{Implementasi Kebijakan Pemanfaatan Sewa Tanah Pengairan Solo Valley Warken di Kabupaten Lamongan}

Sebagai salah satu daerah dengan aset pengairan potensial, yaitu Tanah Solo Valley Warken, berikut adalah implementasi kebijakan pemanfaatan sewa Tanah Pengairan Solo Valley Warken Kabupaten Lamongan dengan studi empiris di Desa Pelangwot dan Desa Sedayulawas, dimana penulis menggunakan enam variabel atau faktor implementasi kebijakan Van Meter \& Van Horn untuk mendiskripsikan dan menganalisis data, yaitu sebagai berikut:

\subsubsection{Standar Sasaran Kebijakan atau Ukuran Yang Harus Dicapai}

Standar sasaran dan ukuran yang ingin dicapai kebijakan merupakan variabel utama dalam teori implementasi kebijakan Van Meter \& Van Horn (dalam Budi Winarno, 2016, h. 142) yang menentukan keberhasilan dalam implementasi kebijakan, karena adanya standar sasaran tersebut berpengaruh terhadap 
pelaksanaan kebijakan, mempengaruhi kecenderungan implementator melalui komunikasi yang mereka lakukan.

Perjanjian kerjasama antara PJT I dengan Pemerintah Kabupaten Lamongan tentang Pemanfaatan dan Pengamanan Tanah Eks PI-PWS Bengawan Solo dan Tanah Solo Valley Warken; berdasarkan keputusan bersama antar keduanya No. 32 Tahun 2002 yang ditandatangani pada tanggal 27 Agustus 2002, merupakan kesepakatan dalam bentuk yang saling menguntungkan. PJT I bertujuan untuk menambah pendapatannya dari hasil pemanfaatan aset-aset pengairan yang potensial guna menambah pembiayaan pelaksanaan tugas pokok, seperti penyelenggaraan Sistem Penyediaan Air Minum (SPAM) dan penyediaan listrik.

Sedangkan, Pemerintah Kabupaten Lamongan bertujuan untuk memanfaatkan aset pengairan, Tanah Solo Valley Warken, adalah guna meningkatkan tingkat Pendapatan Asli Daerah dengan penetapkan target setoran retribusi sewa hasil pemanfaatan tiap tahunnya. Dimana dalam empat tahun terakhir ini, Tahun 2016 hingga Tahun 2019, besaran target retribusi sewa atas Tanah Pengairan Solo Valley tersebut, secara efektif terpenuhi dengan paparan data dalam tabel sebagai berikut:

Tabel 1 Retribusi Sewa Tanah Pengairan Solo Valley dan Target Retribusi Tahun 2016-2019

\begin{tabular}{|l|l|c|c|c|c|}
\hline \multirow{2}{*}{ No } & \multicolumn{1}{|c|}{ Uraian } & \multicolumn{4}{|c|}{ Tahun } \\
\cline { 3 - 6 } & $\mathbf{2 0 1 6}$ & $\mathbf{2 0 1 7}$ & $\mathbf{2 0 1 8}$ & $\mathbf{2 0 1 9}$ \\
\hline 1 & $\begin{array}{l}\text { Retribusi } \\
\text { sewa tanah } \\
\text { Solo Valley }\end{array}$ & 31.055 .025 & 150.471 .950 & 75.083 .250 & 75.024 .500 \\
\hline 2 & $\begin{array}{l}\text { Retribusi } \\
\text { target }\end{array}$ & 31.000 .000 & 150.000 .000 & 75.000 .000 & 75.000 .000 \\
\hline
\end{tabular}

Sumber: LKPJ Dinas PU SDA Kabupaten Lamongan 2016 - 2018, serta dokumen Dinas PU SDA 2019, diolah penulis

Tingkat keberhasilan dalam pemenuhan target retribusi sewa tanah Solo Valley Warken dan tanah pengairan lainnya, sebagaimana penulis sampaikan sebelumnya, sangat berpotensi untuk ditingkatkan. Terlebih adanya keterlibatan Perusahaan Jasa Tirta I, sebagai pihak profesional dalam pengelolaan aset, yang diharapkan dapat membantu pendayagunaan aset pengairan secara lebih optimal dan berwawasan lingkungan. Partisipasi perusahaan profesional dalam pengelolaan aset negara tersebut, merupakan bentuk good governance atau tata pemerintahan yang baik guna meningkatkan manajemen aset secara lebih profesional, sehingga memiliki fungsi manajemen yang lebih baik.

\subsubsection{Ketersediaan Sumber Daya: Sumber Daya Manusia dan Sumber Daya Finansial}

Sebagaimana Abdul Wahab (2012, h. 179) mengemukakan bahwa, keberhasilan atau kegagalan suatu implementasi kebijakan dapat dilihat dari kemampuan implementator secara nyata dalam meneruskan serta mengoperasikan program-program yang telah dirancang. Dengan kata lain, sumber daya manusia dalam implementasi kebijakan publik, adalah instrumen utama yang menjadi kunci apakah suatu kebijakan terimplementasi dengan baik atau tidak.

Dalam pelaksanaan kebijakan pemanfaatan sewa tanah pengairan Solo Valley Warken di Kecamatan Laren dan Kecamatan Brondong Kabupaten Lamongan, sumber daya manusia yang diberikan tugas atas implementasinya, dipimpin oleh Kepala Unit Pelaksanaan Teknis Pengelola Sumber Daya Air Karanggeneng yang berada dibawah Dinas Pekerjaan Umum Sumber Daya Air. Ka. UPT PSDA Karanggeneng, bertanggungjawab atas pengelolaan sumber pengairan, termasuk Tanah Solo Valley Warken yang berada diwilayah Kecamatan Laren, Kecamatan Brondong, Kecamatan Solokuro, Kecamatan Paciran, Kecamatan Karanggeneng, Kecamatan Maduran, Kecamatan Kalitengah, dan Kecamatan Sekaran. Kepala UPT PSDA Karanggeneng, dalam melaksanakan tugasnya dalam lingkup wilayah kerjanya untuk mengimplementasikan kebijakan pemanfaatan sewa Tanah Solo Valley Warken, dibantu oleh satu orang juru pengairan yang bertugas dilapangan baik pengawasan, pembuatan data terkait operasi, dan pemeliharaan.

Secara kuantitas, implementator dalam kebijakan pemanfaatan sewa Tanah Pengairan Solo Valley Warken di Kabupaten Lamongan dalam lingkup wilayah UPT. PSDA Karangeneng, adalah kurang. Hal tersebut, akan berdampak pada pelayanan yang diberikan oleh implementator. Tugas implementator dalam pengimplementasian kebijakan sewa atas Tanah Solo Valley Warken ini, merupakan tugas tambahan, disamping tugasnya sebagai juru pengairan.

Adanya rangkap tugas tersebut, menjadikan ruang gerak dan waktu implementator menjadi sangat terbatas, baik dalam pelaskanaan tugas pengairannya sebagai juru pengairan, maupun dalam melaksanakan tugasnya sebagai implementator dalam kebijakan sewa Tanah Pengairan Solo Valley Warken di Kabupaten Lamongan pada wilayah UPT PSDA Karanggeneng.

Selain, sumber daya manusia, sumber daya finansial juga harus tersedia untuk kepentingan kelancaran administrasi dalam pengimplementasian kebijakan sewa atas Tanah Pengairan Solo Valley Warken di Kabupaten Lamongan. Dalam Peraturan Menteri Keuangan No. 57/ PMK.06/ 2016 tentang Tata Cara Pelaksanaan Sewa Barang Milik Negara, seluruh biaya operasional, biaya pembuatan perjanjian sewa, biaya pemeliharaan, dan biaya perbaikan merupakan tanggung jawab penyewa atau pemegang izin.

Dalam dokumen yang penulis dapatkan selama penelitian, untuk biaya operasional dalam kebijakan pemanfaatan sewa Tanah Solo Valley Warken, adalah $10 \%$ dari total setoran retribusi pemanfaatan yang didapat 
guna biaya perjalanan dinas, ATK, dan honorarium petugas. Berikut penulis uraikan sumber daya operasional dari Tahun 2016 hingga Tahun 2019 dalam mata uang rupiah pada tabel berikut ini:

Tabel 2 Nominal Dana Operasional Implementasi

Pemanfaatan Sewa Tanah Pengairan Solo Valley Warken

\begin{tabular}{|c|c|c|l|l|}
\hline Tahun 2015 & Tahun 2016 & Tahun 2017 & Tahun 2018 & Tahun 2019 \\
\hline $3.112 .4997,5,-$ & $3.105 .502,5,-$ & $15.047 .195,-$ & $7.508 .325,-$ & $7.502 .450,-$ \\
\hline
\end{tabular}

Sumber: LKPJ 2016-2018; dokumen 2019 (diolah penulis)

Berdasarkan pemaparan diatas biaya dalam pengimplementasian tugasnya sebagai implementator dalam hal operasional dan pemenuhan persyaratan izin sewa pemohon atas Tanah Pengairan Solo Valley Warken, menjadi tanggung jawab pemohon atau calon penyewa.

\subsubsection{Karakteristik Badan Pelaksana atau Struktur Birokrasi}

Indikator yang berkaitan dengan struktur birokrasi antara lain, adalah diberlakukannya Standard Operational Procedure (SOP) dari Pemerintah Kabupaten Lamongan untuk pelaksanaan kebijakan pemanfaatan sewa barang milik negara yang berada didalam kuasanya, dalam kaitan dengan ini adalah Tanah Pengairan Solo Valley Warken. SOP tersebut berkaitan dengan pola hubungan kerja antara Dinas PU Sumber Daya Air dengan bagian-bagian fungsional dalam instansinya untuk melaksanakan kebijakan pemanfaatan sewa tanah Solo Valley Warken di Kabupaten Lamongan.

Dwiyanto (2008, h. 94), mengemukakan bahwa struktur birokrasi merupakan suatu alat atau instrumen untuk menjaga suatu prosedur kerja yang telah disepakati bersama. Standar kerja atau dikenal dengan istilah Standard Operating Prosedure, merupakan dokumen dengan serangkaian aturan tertulis yang dibakukan mengenai berbagai proses penyelenggaraan administrasi yang berisi teknis pekerjaan, peraturan hasil koordinasi bersama secara internal (Insani, 2010, h. 11).

Standar Operasional Kerja yang dimiliki, berhubungan dengan Peraturan Bupati Lamongan No. 10 Tahun 2010 tentang Pedoman Pemakaian Tanah - Tanah; yang dikuasai oleh Pemerintah Kabupaten Lamongan. Adapun ketentuan retribusi atau sewa atas pemanfaatan Tanah Solo Valley Warken dan tanah pengairan lainnya, adalah berdasarkan Peraturan Daerah Kabupaten Lamongan No. 9 Tahun 2019 tentang Perubahan Kedua Atas Peraturan No. 18 Tahun 2010 tentang Retribusi Daerah No. 18 Tahun 2010 tentang Retribusi Pemakaian Kekayaan Daerah. Dimana penyetoran retribusi dilakukan melalui Bank Daerah yang dalam hal ini adalah Bank Pembangunan Daerah Jawa Timur.

Terkait kinerja implementator diwilayah UPT PSDA Karanggeneng, sudah berdasarkan alur yang ditetapkan oleh Dinas PU Sumber Daya Air Kabupaten Lamongan. Dalam hal pengawasan yang fleksibel dan belum adanya tindakan yang tegas dari pihak implementator, merupakan bentuk tahapan dalam proses atau transisi perubahan yang muncul dalam masyarakat yang sudah turun menurun memanfaatkannya. Atau bisa dikatakan sebagai pemberian ruang bagi proses kebijakan untuk dapat diterima oleh masyarakat.

Koordinasi, dilakukan minimal sekali dalam satu bulan, bertujuan agar apa yang dilaksanakan oleh petugas lapangan seragam dan tidak ada yang menyimpang dari tujuan dan sasaran kebijakan. Koordinasi tersebut, juga menjadi wadah dalam pemberian rekomendasi solusi atas masalah-masalah yang terjadi dilapangan oleh atasan yang mempunyai kompetensi dan kecakapan dibidangnya masing-masing. Adanya koordinasi, menunjukkan keterbukaan antara implementator dengan UPT PSDA Karanggeneng serta Dinas PU Sumber Daya Air Kabupaten Lamongan untuk bersama-sama mencapai target tujuan atau sasaran yang telah ditetapkan.

\subsubsection{Komunikasi Antar Organisasi}

Agustino (2006, h. 157), mengemukakan bahwa komunikasi merupakan salah satu variabel atau faktor yang penting dalam mempengaruhi tingkat keberhasilan suatu implementasi kebijakan publik, dalam pencapaian tujuannya. Komunikasi yang tersampaikan dengan baik, berdampak pada kejelasan metode kerja atau prosedur kerja yang dipahami oleh semua implementator. Sehingga setiap keputusan dalam suatu kebijakan publik harus dapat disampaikan atau dikomunikasikan dengan tepat. Selain itu, ketepatan tersebut juga harus dapat dipahami dengan jelas dan dengan pemahaman yang konsisten.

Dalam melaksanakan tugasnya untuk menyampaikan informasi, pembinaan, pengawasan mengenai kebijakan pemanfaatan sewa atas Tanah Pengairan Solo Valley Warken di Kabupaten Lamongan yang berada dalam wilayah UPT PSDA Karanggeneng, juru pengairan selaku petugas lapangan (implementator) menggunakan metode sosialisasi person to person dengan dibantu dengan masyarakat yang ditunjuk oleh desa. Meskipun metode sosialisasi dipandang sebagai teknik klasik dibandingkan komunikasi dengan menggunakan media elektronik yang modern, tetapi dengan teknik ini implementator dapat memahami suatu interaksi sosial yang nantinya dapat menjadi rumusan atau bahan dalam mengatasi kendala-kendala yang ada dalam masyarakat. Dimana, pendekatan-pendekatan dalam interaksi sosial tersebut, secara perlahan dapat menggiring interpretasi dan sikap penerimaan masyarakat terhadap urgensi diberlakukannya suatu kebijakan publik tersebut.

Terkait dengan implementasi kebijakan pemanfaatan sewa Tanah Pengairan Solo Valley Warken 
di Kabupaten Lamongan, dalam wilayah UPT PSDA Karanggeneng, para implementator mempunyai keseragaman dalam tujuan diberlakukannya kebijakan tersebut, yaitu untuk meningkatkan Pendapatan Asli Daerah Kabupaten Lamongan. Dan dengan alur yang sesuai dengan mekanisme yang telah ditetapkan, yaitu: Pertama, komunikasi antara pemohon dan petugas lapangan terkait kelengkapan berkas. Kedua, Komunikasi untuk meninjau lapangan dalam hal peruntukan tanah, pengukuran tanah, yang kemudian hasilnya dikomunikasikan kepada kepala desa, camat dan kepala UPT. Ketiga, petugas lapangan melakukan komunikasi kepada Dinas PU SDA Kabupaten Lamongan untuk meminta rekomendasi, pertimbangan teknik, dan koreksi yang kemudian disahkan untuk selanjutnya diajukan kepada kepala daerah melalui dinas penanaman modal dan PTSP.

Dengan kata lain, komunikasi dalam lingkup pelaksana merupakan proses penyampaian informasi pengimplementasian untuk mengetahui apa yang harus dilakukan dan apa yang telah dilakukan untuk mencapai tujuan yang telah ditetapkan. Dimana keberhasilannya terletak dari penyampaian yang baik serta kejelasan dan konsistensi substansi yang disampaikan.

\subsubsection{Disposisi atau Kecenderungan Sikap Implementator}

Disposisi mencakup komitmen implementator dalam melaksanakan tugasnya, fungsi, wewenang, dan tanggung jawabnya sesuai dengan peraturan yang ditetapkan. Jika implementator memiliki kecenderungan sikap yang baik, maka kebijakan akan terimplementasikan dengan baik. Disposisi atau kecenderungan sikap ini juga harus diseragamkan antara implementator kebijakan, karena kecenderungan yang berbeda antar implementator juga menjadikan suatu kebijakan tidak terimplementasikan dengan baik.

Dalam kaitannya dengan implementasi kebijakan pemanfaatan sewa Tanah Pengairan Solo Valley di Kabupaten Lamongan, dari petugas yang ada di Dinas PU SDA Kabupaten Lamongan, UPT PSDA Karanggeneng serta petugas lapangan, menunjukkan adanya komitmen dalam melaksanakan tugasnya untuk menjadikan kebijakan pemanfaatan sewa tersebut berhasil serta dapat meningkatkan kemampuan pengelolaan aset untuk menambah Pendapatan Asli Daerah (PAD) yang menjadi tujuan atau sasaran kebijakan.

Dengan sudah ditetapkannya sasaran dalam penetapan target besaran retribusi sewa tiap tahunnya, mempengaruhi sikap dan kecenderungan implementator dalam mengimplementasikan kebijakan. Selama target tahunan terpenuhi, adanya pelanggaran izin yang terjadi dilapangan, juga hanya ditindak dengan teguran verbal dan selama tidak melanggar pedoman penggunaan tanah negara.

\subsubsection{Kondisi Ekonomi, Sosial dan Politik}

Kondisi sosial, ekonomi dan politik yang terjadi dilingkungan masyarakat merupakan salah satu indikator yang dapat mempengaruhi apakah suatu kebijakan publik terimplementasi dengan baik ataukah tidak (Winarno, 2016, h. 142 -149). Dimana dalam variabel ini, grup target menunjukkan respons dari pemberlakuan suatu kebijakan publik, yang nantinya respons tersebut akan berpengaruh pada tingkat keberhasilan dari implementasi kebijakan publik.

Desa Pelangwot, merupakan salah satu dari 20 desa yang ada di Kecamatan Laren, dengan luas $14,57 \mathrm{Km}^{2}$ dan termasuk wilayah dataran rendah dengan ketinggian rata-rata $\pm 4,49 \mathrm{~m}$ diatas permukaan laut. Desa Pelangwot, merupakan salah satu desa yang setiap tahunnya dilanda banjir. Pasca dibangunnya Floodway, bencana banjir karena Air Bengawan Solo yang meluap terminimalisir, tetapi banjir yang disebabkan curah hujan yang tinggi, masih tetap terjadi dikarenakan kondisi lingkungannya yang merupakan dataran rendah.

Dalam kondisi tersebut, mengakibatkan tanah pengairan Solo Valley Warken yang mayoritas peruntukannya adalah tanah pertanian, hanya bisa dimanfaatkan untuk satu kali tanam dalam setahun. Dan menjadi salah satu faktor tidak terimplementasinya kebijakan sewa di Desa Pelangwot, Kecamatan Brondong. Karena pemakai tanah mempertimbangkan besaran manfaat yang diterima dengan potensi banjir yang belum bisa teratasi dengan baik.

Sedangkan, di Desa Sedayulawas, merupakan salah satu desa dari sembilan desa yang ada di Kecamatan Brondong, dengan luas $10.64 \mathrm{Km}^{2}$ dan merupakan daerah pantura dengan akses jalan provinsi. Lokasinya yang dekat dengan akses jalan, menjadikan lokasi tersebut strategis bagi kegiatan usaha maupun kemudahan akses untuk hunian. Kondisi tersebut menjadi salah satu faktor banyaknya izin peruntukan sewa Tanah Solo Valley Warken dengan peruntukan hunian maupun kegiatan usaha.

Berdasarkan uraian tersebut, dapat diambil kesimpulan bahwa adanya manfaat ekonomi dengan didukung dengan minimnya permasalahan dalam lingkup lingkungan tersebut, serta partisipasi dari aparatur desa, dapat menjadi faktor yang mempengaruhi berhasil atau tidaknya implementasi suatu kebijakan publik.

\subsection{Faktor Penghambat dan Faktor Pendukung Implementasi Kebijakan Pemanfaatan Sewa Tanah Pengairan Solo Valley Warken di Kabupaten Lamongan}

\subsubsection{Faktor Penghambat}


Pertama, pengimplementasian kebijakan pemanfaatan sewa Tanah Pengairan Solo Valley Warken, di Desa Plangwot dan Desa Sedayulawas, juru pengairan sebagai petugas lapangan bersama-sama dengan UPT PSDA Kranggeneng dan Dinas PU SDA Kabupaten Lamongan, dalam pengimplemntasian kebijakan yang baik dan benar. Selain, SDM yang kompeten, Sumber Daya Keuangan juga menjadi faktor pendukung terimplementasinya suatu kebijakan publik. Dalam hal kebijakan pemanfaatan sewa Tanah Pengairan Solo Valley di Kabupaten Lamongan, $10 \%$ dari setoran retribusi sewa dialokasikan untuk biaya operasional guna perjalanan dinas, ATK, dan honorarium petugas. Hal ini, akan mendorong motivasi petugas lapangan dalam melaksanakan tugasnya.

Kedua, koordinasi hulu ke hilir antar lembaga. Koordinasi merupakan kegiatan yang erat dengan fungsi manajemen, dari perencanaan, pengorganisasian, pelaksanaan, dan pengawasan. Koordinasi merupakan proses mengintegrasikan suatu tujuan dan kegiatan antar bidang fungsional agar tercapai tujuan bersama (Handoko, 2007, h. 195). Dalam hal implementasi kebijakan pemanfaatan sewa Tanah Pengairan Solo Valley Warken di Kabupaten Lamongan, koordinasi antar satuan lembaga dilakukan secara berkala, sekali dalam satu bulan. Tujuan dari adanya koordinasi tersebut adalah untuk menciptakan kerjasama yang terpadu dalam penyelesaian masalah ataupun pencapaian tujuan.

Ketiga, adanya partisipasi dari masyarakat untuk menciptakan tertib pemanfaatan sewa Tanah Pengairan Solo Valley Warken dengan prosedur yang sah. Dimana Waras sebagai juru pengairan, yang bertugas dilapangan dibantu oleh Nur Zen Wahid yang ditunjuk oleh Kepala Desa Sedayulawas guna penertiban perizinan atas pemanfaatan sewa Tanah Pengairan Solo Valley Warken.

Keempat, adanya partisipasi dari pemerintahan desa dalam mengoptimalkan kewenangan pengelolaannya atas desa wilayahnya untuk melihat potensi dari keberadaan aset negara yang apat dimanfaatkan untuk kepentingan desa dan masyarakat serta untuk percepatan pembangunan desa.

Kelima, masuknya perusahaan besar dengan metode efektif dalam penanganan potensi gagal panen/ produksi. Modal yang besar dan profesionalitas pengusaha, menjadikan manajemen atas usahanya juga dapat berjalan dengan baik. Masuknya metode pengelolaan yang baru dan dapat meminimalisir resiko gagal produksi (panen), menjadikan jenis usaha dan metode tersebut banyak ditiru. Sehingga banyaknya usaha yang berhasil menjadi peluang adanya lapangan kerja bagi penyerapan tenaga kerja.

\subsubsection{Faktor Pendukung}

Pertama, suatu program dalam konteks implementasi kebijakan publik, selain membuat rancang bangun program, bentuk pelaksanaan juga harus adanya suatu monitoring dan sarana-sarana pengawasan tepat guna, serta evaluasi agar suatu kebijakan publik dapat diimplementasikan dengan baik (Tachjan, 2006, h. 35). Tanah Solo Valley Warken di Desa Pelangwot, Kecamatan Laren seluas $529.913 \mathrm{~m}^{2}$ dengan nilai aset Rp. 105.982.000,- yang dimanfaatkan oleh 332 nama tanpa tanpa izin merupakan bentuk kurangnya monitoring, pembinaan, dan minimnya pengawasan dan tindak penertiban atas pelanggaran dan pemanfaatan yang tidak sesuai, baik dari PJT I maupun dari Dinas PU SDA Kabupaten Lamongan. Sehingga implementasi kebijakan pemakaian sewa atas Tanah Pengairan Solo Valley Warken di Desa Pelangwot Kecamatan Laren, tidak terimplementasi dengan baik.

Kedua, kurangnya personel lapangan. Selain kualitas dari Sumber Daya Manusia, dibutuhkan juga kuantitas dari petugas lapangan dalam mengimplementasikan kebijakan publik secara efesien dan efektif. Penulis sampaikan sebelumnya, bahwa setiap UPT PSDA yang ada didaerah otonom Kabupaten Lamongan hanya memiliki satu juru pengairan yang bertugas dilapangan untuk mengimplementasikan kebijakan pemanfaatan sewa atas Tanah Pengairan Solo Valley Warken yang ada di Kabupaten Lamongan.

Ketiga, sikap apatis merupakan sikap acuh dan bentuk ketidakpedulian masyarakat atas adanya suatu kebijakan. Waras menyampaikan dalam wawancara pada tanggal 22 Juni 2020, bahwa banyak sekali pelanggaran atas pemanfaatan Tanah Solo Valley Warken, seperti sebagai berikut:

a) Terputusnya informasi pemanfaatan akibat pihak pemakai meninggal dan kemudian timbul perseteruan dengan ahli waris;

b) Penggunaan lahan tanpa izin yang sah;

c) Peralihan hak pakai tanpa melalui prosedur yang sah; dan

d) Menghindar dari pembayaran retribusi sewa dengan sengaja, sehingga perlu adanya pembinaan dan sosialisasi mendalam agar aset negara dapat dimanfaatkan dengan nilai kemanfaatan sebesarbesarnya.

e) Keempat, tradeoff antara manfaat dan biaya yang dikeluarkan. Adanya pertimbangan tersebut dilatarbelakangi dengan adanya Tanah Solo Valley yang berada didaerah rawan banjir. Kondisi rawan banjir tersebut, menjadikan manfaat ekonomi belum bisa dimanfaatkan oleh pemakai. Sehingga adanya 
tindakan pemakaian tanpa izin yang berpengaruh terhadap tingkat keberhasilan sautu implementasi kebijakan publik.

\subsection{Kontribusi Pemanfaatan Sewa Tanah Pengairan Solo Valley Warken terhadap PAD Kabupaten Lamongan}

Suatu daerah mampu otonom, apabila: Pertama, daerah tersebut memiliki kemampuan dan kewenangan dalam menggali aset-aset ataupun sumber-sumber keuangan, mengelola, dan hasilnya digunakan untuk membiayai fungsi penyelenggaraan pemerintahan. Kedua, daerah tersebut meminimalisir bantuan pusat, dengan menjadikan sumber PAD sebagai sumber keuangan terbesarnya (Halim \& Damayanti, 2011, h. 253). Dengan kata lain, kemampuan daerah dalam menggali aset-aset yang dimilikinya, akan berperan pada peningkatan keuangan daerah serta mendorong terwujudnya daerah yang otonom.

Perjanjian kerjasama antara Pemerintah Kabupaten Lamongan dengan PJT I tentang Pemanfaatan dan Pengamanan Tanah Eks PI-PWS Bengawan Solo dan Tanah Solo Valley Warken di Kabupaten Lamongan, berdasarkan Keputusan Bersama Bupati Lamongan dan Direktur Perusahaan Umum Jasa Tirta I No. 32 Tahun 2002 pada tanggal 27 Agustus 2002; membawa kontribusi dengan pembagian hasil setelah dikurangi $10 \%$ guna biaya operasional antara kedua belah pihak, dengan Prosentase $70 \%$ untuk Pemerintah Kabupaten Lamongan dan $30 \%$ untuk PJT I.

Pendapatan Asli Daerah yang diperoleh retribusi sewa atas pemanfaatan aset Tanah Pengairan Solo Valley Warken di Kabupaten Lamongan, dari Tahun 2016 hingga 2019 adalah: Rp. 19.564.665,75 pada Tahun 2016; Rp. 94.797.328,5 pada Tahun 2017; Rp. 47.302.447 pada Tahun 2018; serta sebesar Rp. 47.265.435 pada Tahun 2019.

Tabel 3 Kontribusi Retribusi Sewa Tanah Solo Valley

Warken Terhadap Pendapatan Asli Daerah (PAD) Kabupaten Lamongan

\begin{tabular}{|l|r|r|r|r|r|}
\hline \multirow{3}{*}{ Tahun } & \multicolumn{3}{|c|}{ Hasil Retribusi Pemanfaatan Tanah Pengairan Solo Valley } & \multirow{2}{*}{$\begin{array}{l}\text { PAD Kab. } \\
\text { Wamongan }\end{array}$} \\
\cline { 2 - 5 } & Target & Total Hasil Kabupaten Lamongan & \multicolumn{1}{|c|}{$\begin{array}{l}\text { Kontribusi } \\
\text { PAD (70 \%) }\end{array}$} & $\begin{array}{l}\text { l JT I } \\
(\mathbf{3 0 \% )}\end{array}$ & \\
\hline 2016 & 31.000 .000 & 31.055 .025 & $19.564 .665,75$ & $8.384 .8856,75$ & $317.130 .114 .464,67$ \\
\hline 2017 & 150.000 .000 & 150.471 .950 & $94.797 .328,5$ & $40.627424,5$ & $413.033 .141 .634,00$ \\
\hline 2018 & 75.000 .000 & 75.083 .250 & 47.302 .447 & $20.272 .477,5$ & $471.567 .901 .740,00$ \\
\hline 2019 & 75.000 .000 & 75.024 .500 & 47.265 .435 & 20.265 .615 & $503.985 .109 .600,00$ \\
\hline
\end{tabular}

Sumber: Sumber: LKPJ Dinas PU SDA Kabupaten 2016-2019 \& BPKAD Kab. Lamongan 2019 (diolah)

Bagi hasil dalam kerjasama antara Pemerintah Kabupaten Lamongan dengan PJT I atas pemanfaatan tanah Eks PI-PWS Bengawan Solo pada Tahun 2016 hingga Tahun 2019, memberi kontribusi atas Pendapatan Asli Daerah (PAD) sebesar, yaitu

- $0.06 \%$ pada Tahun 2016;

- $0,02 \%$ pada Tahun 2017;

- $0,01 \%$ pada Tahun 2018; dan
- $0,08 \%$ pada Tahun 2019.

Rasio efektifitas antara target penerimaan retribusi dengan realisasi penerimaan retribusi dari Tahun 2016 hingga Tahun 2019, menggunakan metode penghitungan sebagai berikut:

$$
\text { Rasio Efektivitas }=\frac{\text { Realisasi Penerimaan Retribusi }}{\text { Target Penerimaan Retribusi }} \times 100 \%
$$

Rasio efektifitas antara target penerimaan retribusi dengan realisasi penerimaan retribusi dari Tahun 2016 hingga Tahun 2019 terpenuhi, dapat disimpulkan bahwa kemampuan implementator atas kebijakan pemanfaatan sewa Tanah Pengairan Solo Valley Warken di Kabupaten Lamongan; dalam memobilisasi penerimaan sesuai dengan apa yang ditargetkan sudah efektif. Akan tetapi, kontribusinya terhadap Pendapatan Asli Daerah dari Tahun 2016 hingga Tahun 2019 masih jauh dibawah ratarata. Hal tersebut dikarenakan kurangnya tingkat manajemen aset yang dibawah daerah otonomnya, terkait Inventarisasi Aset, Legal Audit, Penilaian Aset, Optimalisasi Aset, dan Pengembangan Sistem Informasi Manajemen Aset (SIMA). Lima aspek yang harus dilakukan Pemerintah Kabupaten Lamongan tersebut, bertujuan untuk menciptakan tertib administrasi, pengamanan aset, pengendalian aset, dan pengawasan aset.

\section{Kesimpulan}

\subsection{Implementasi Kebijakan Pemanfaatan Sewa Tanah Pengairan Solo Valley Warken di Kabupaten Lamongan}

Pertama, standar sasaran kebijakan/ ukuran dan tujuan yang harus dicapai: Perjanjian kerjasama antara PERUM Jasa Tirta I dengan Pemerintah Kabupaten Lamongan tentang Pemanfaatan dan Pengamanan Tanah Eks PI-PWS Bengawan Solo dan Tanah Solo Valley Warken; berdasarkan keputusan bersama antar keduanya No. 32 Tahun 2002 yang ditandatangani pada tanggal 27 Agustus 2002, merupakan kesepakatan dalam bentuk yang saling menguntungkan.

Kedua, ketersediaan sumber daya: sumber daya manusia dan sumber daya finansial. Kuantitas yang ada sangat minim, dimana tiap UPT (Unit Pelaksana Teknis) PSDA, hanya memiliki satu juru pengairan, yang bertugas sebagai fasilitator perantara masyarakat dilapangan dengan Dinas PU SDA Kabupaten Lamongan.

Sumber dana dalam implementasi kebijakan pemanfaatan sewa Tanah Pengairan Solo Valley Warken, adalah dari $10 \%$ hasil retribusi sewa yang digunakan untuk biaya perjalanan dinas, ATK, dan honorarium petugas.

Ketiga, komunikasi antar organisasi. Berdasarkan alur permohonan izin pemanfaatan hingga dikeluarkannya izin pemanfaatan sewa atas Tanah 
Pengairan Solo Valley Warken di Kabupaten Lamongan, komunikasi antar bidang fungsional berjalan secara terbuka, dapat dipahami dan konsisten. Sedangkan penyampaian informasi ke grup target/ masyarakat dalam bentuk sosialisasi dan pembinaan dilaksanakan menggunakan pendekatan personal.

Keempat, karakteristik badan pelaksana atau struktur birokrasi. Meski adanya komunikasi yang terbuka antar implementator dalam bidang-bidang fungsional, karakteristik dalam pola hubungan yang ada tetap menonjolkan posisi dominan atasan untuk mengontrol dan mengawasi setiap kegiatan bawahannya, dengan minimum mengadakan koordinasi sekali dalam satu bulan. Dominasi atasan tersebut berujuan untuk menjaga keselarasan sasaran yang ingin dicapai dalam kebijakan pemanfaatan sewa Tanah Pengairan Solo Valley Warken.

Kelima, disposisi atau kecenderungan sikap implementator. Orientasi untuk memenuhi target retribusi yang telah ditetapkan, berpengaruh kepada kecenderungan sikap para implementator, dimana, selama target terpenuhi, bentuk pelanggaran pemanfaatan yang ada, hanya ditegur secara verbal selama tidak ada pemanfaatan tanah diluar peruntukan tanah yang sudah ditetapkan dalam Tata Ruang Wilayah, serta tanah tersebut belum digunakan bagi kepentingan pengairan, daerah ataupun daerah.

Keenam, Kondisi ekonomi, sosial, dan politik. Masyarakat Desa Pelangwot, Kecamatan Laren, mayoritas berprofesi sebagai petani, dan pemanfaatan tanah pengairan Solo Valley Warken yang ada didaerah tersebut adalah diperuntukkan untuk pertanian. Letaknya yang berada dalam dataran rendah, pasca dibangunnya floodway bencana banjir tetap terjadi melalui hujan, sehingga adanya pertimbangan biaya dan manfaat yang menjadikan banyaknya lahan yang digunakan tanpa izin, sedangkan tertib izin atas Pemanfaatan Solo Valley Warken di Desa Sedayulawas, dilatarbelakangi adanya pemanfaatan yang secara permanen manfaatnya dirasakan oleh pemegang izin, dengan lokasi yang strategis sebagai hunian.

\subsection{Faktor Pendukung dan Penghambat Implementasi Kebijakan Pemanfaatan Sewa Tanah Pengairan Solo Valley Warken di Kabupaten Lamongan}

Faktor pendukung, yang harus dipertahankan dalam implementasi kebijakan pemanfaatan sewa. Penulis mengklasifikasikan faktor pendukung dalam implementasi kebijakan pemanfaatan sewa Tanah Pengairan Solo Valley Warken dalam dua bagian, yaitu faktor internal yang meliputi sumber daya yang kredibel, adanya koordinasi dari hulu ke hilir, serta sumber daya keuangan yang sudah ditetapkan untuk operasional implementasi kebijakan pemanfaatan sewa Tanah Pengairan Solo Valley Warken Kabupaten Lamongan.
Sedangkan, faktor eksternal yang meliputi adanya partisipasi masyarakat atau pihak swasta dalam pelaksanaannya yang tunjuk oleh kepala desa untuk membantu juru pengairan dalam menertibkan izin pemanfaatan sewa Tanah Pengairan Solo Valley Warken.

Kedua, faktor penghambat, yang harus diminimalisir dan diusahakan untuk dihilangkan. Penulis mengklasifikasikan faktor penghambat kedalam dua bagian, yaitu faktor internal dari segi pengawasan dan penertiban yang kurang, baik pengawasan dari Dinas PU SDA Kabupaten Lamongan ataupun dari PJT I; dan faktor eksternal dari sikap apatis masyarakat yang tidak peduli dengan adanya kebijakan serta aturan yang ada, kondisi lingkungan yang permasalahannya harus diatasi, sehingga tidak menimbulkan adanya tradeoff antara manfaat pemanfaatan dan biaya pemanfaatannya.

\subsection{Kontribusi Pemanfaatan Sewa Tanah Pengairan Solo Valley Warken Terhadap PAD Kabupaten Lamongan}

Pendapatan Asli Daerah yang diperoleh retribusi sewa atas pemanfaatan aset Tanah Pengairan Solo Valley Warken di Kabupaten Lamongan, dari Tahun 2016 hingga Tahun 2019 adalah sebesar Rp. 19.564.665,75. Adapun pada Tahun 2016 sebesar Rp. 94.797.328,5; pada Tahun 2017 sebesar Rp. 47.302.447; kemudian pada Tahun 2018; dan senilai Rp. 47.265.435 pada Tahun 2019. Atau dengan kata lain proporsi kontribusi atas Pendapatan Asli Daerah adalah sebesar yaitu sebagai berikut:

- $0,06 \%$ pada Tahun 2016 ;

- $0,02 \%$ pada Tahun 2017 ;

- $0,01 \%$ pada Tahun 2018; dan

- $0,08 \%$ pada Tahun 2019.

\section{Daftar Pustaka}

Agustino, L. (2006). Politik dan Kebijakan Publik. Bandung: AIPI.

Chomzah, H.A.A. (2002). Hukum Pertanahan: Seri Hukum Pertanahan I \& II. Jakarta: Prestasi Pustaka.

Dwiyanto, A. (2008). Mewujudkan Good Governance Melalui Pelayanan Publik. Yogyakarta: Gadja Mada University Press.

Halim, Abdul., \& Damayanti, Theresia. (2011). Pengelolaan Keuangan Daerah, Edisi Kedua, Cetakan Pertama. Yogyakarta: UPP YKPN

Hanafi, M.M. (2003). Manajemen. Yogyakarta: UPP AMP YKPN.

Handoko, H.T. (2007). Manajemen Personalia dan Sumber Daya Manusia. Yogyakarta: BPFE.

Insani, I. (2010). Standar Operasional Prosedur (SOP) sebagai pedoman Pelaksanaan Administrasi Perkantoran dalam Rangka Peningkatan 
Pelayanan dan Kinerja Organisasi Pemerintah. Penyempurnaan Makalah pada Workshop Manajemen Perkantoran di Lingkungan Kementrian Komunikasi dn Informatika. Bandung. Mahmudi. (2009). Manajemen Keuangan Daerah. Yogyakarta: Erlangga.

Moenek, R., \& Suwandana. (2019). Good Governance: Pengelolaan Keuangan Daerah. Bandung: PT. Remaja Rosdakarya.

Siregar, D. D. (2002). Optimalisasi Pemberdayaan Harta Kekayaan Negara. Jakarta: Gramedia Pustaka Utama

Gramedia

(2004). Manajemen Aset. Jakarta:

Sumardjono, M. S.W. (2009). Tanah Dalam Perspektif Hak Ekonomi Sosial dan Budaya. Jakarta: Kompas

Tachjan. (2006). Implementasi Kebijakan Publik. Bandung: AIPI.

Wahab, A.S. (2012). Analisis Kebijakan dari Formulasi ke Penyusunan Model-Model Implementasi Kebijakan Publik. Jakarta: Bumi Aksara.

Widodo, Joko. (2018). Analisis Kebijakan Publik: Konsep dan Aplikasi Analisi Proses Kebijakan Publik. Malang: Media Nusa Creative.

Winarno, B. (2016). Kebijakan Publik Era Globalisasi. Yogyakarta: CAPS. 